\title{
Does kinesiotaping can improve static stability of the knee after anterior cruciate ligament rupture? A randomized single- blind, placebo-controlled trial
}

Katarzyna Ogrodzka-Ciechanowicz ${ }^{1 *}$, Grzegorz Głąb ${ }^{1}$, Jakub Ślusarski ${ }^{2}$, Prof Artur Gądek²,3 and Jolanta Nawara ${ }^{4}$

\begin{abstract}
Background: The aim of the study was the assessment of the early impact of the selected kinesiotaping technique on the static stability of the knee joint in patients with $\mathrm{ACL}$ rupture on the basis of stabilographic parameters.

Methods: Sixty-two patients with a complete ACL rupture (32 patients in experimental group and 30 patients in placebo group) took part in the randomized single-blind, placebo-controlled trial. The ligament technique of KT was taken into consideration. Application of a KT tape only on the injured knee was to stabilize the knee joint. Experimental group had application of KT on the injured knee and the placebo group had a KT placebo application (with no tension on KT). Intervention and stabilographic test in both groups was the same.

Research tools included measurements of static stabilographic parameters on stabilometric platform CQStab2P®. Outcome measures were assessed before intervention and after KT application. The analysis included evaluation of outcome variables - total path length, (SP), statokinesiogram path length in the XY axes (SPML, SPAP), and mean velocities in the $X Y$ axes (MV, MVML, MVAP).

Results: The results show a statistically significant shortening of the SP, SPAP and SPML variables only in experimental group. In the placebo group the results were not significant. The analysis also showed a significant improvement in all analyzed variables in the experimental group compared to the healthy side. In the placebo group, the results did not improve significantly after KT application compared to the healthy side.
\end{abstract}

Conclusions: Application o

$\mathrm{f} \mathrm{KT}$ in patients after $\mathrm{ACL}$ rupture shortened the total path length and improved the value of parameters in the frontal and sagittal planes in experimental group, which may suggest the potentially greater improvement in these parameters. By improving the values of the analyzed variables, the KT application is able to compensate for the loss of static stability of the knee.

Trial Registration: This study was registered retrospectively in the Australian New Zealand Clinical Trials Registry (ANZCTR). Registration number: ACTRN12616001407482.

Keywords: Kinesio Tape, Anterior Cruciate Ligament Injuries, Static Stability, Postural Control

\footnotetext{
*Correspondence: katarzynaogrodzka@wp.pl

'Institute of Clinical Rehabilitation, Faculty of Motor Rehabilitation, Institute of

Physical Rehabilitation, University of Physical Education, Al. Jana Pawla II 78,

31-571 Krakow, Poland

Full list of author information is available at the end of the article
}

(C) The Author(s). 2021 Open Access This article is licensed under a Creative Commons Attribution 4.0 International License, which permits use, sharing, adaptation, distribution and reproduction in any medium or format, as long as you give appropriate credit to the original author(s) and the source, provide a link to the Creative Commons licence, and indicate if changes were made. The images or other third party material in this article are included in the article's Creative Commons licence, unless indicated otherwise in a credit line to the material. If material is not included in the article's Creative Commons licence and your intended use is not permitted by statutory regulation or exceeds the permitted use, you will need to obtain permission directly from the copyright holder. To view a copy of this licence, visit http://creativecommons.org/licenses/by/4.0/. The Creative Commons Public Domain Dedication waiver (http://creativecommons.org/publicdomain/zero/1.0/) applies to the data made available in this article, unless otherwise stated in a credit line to the data. 


\section{Background}

To maintain proper postural control of the human body, it is necessary to maintain a balance between proprioception, joint mobility and neuromuscular control [1, 2]. Stability in standing and walking is controlled by musculoskeletal, somatosensory, and vestibular systems [3].

The anterior cruciate ligament (ACL) rupture results in disorders of its function, which in turn affect the changes in the biomechanics of the body [4].

As a result of a failure of ACL function due to an injury, there is loss of knee stability. In particular, anteromedial stability is impaired, which leads to significant deterioration of a patient's ability to maintain a standing position and control of their centre of gravity [4].

It should be noted that knee dysfunction due to ACL rupture is not only related to the loss of mechanical stabilisation. During the injury, there is also impairment of the receptors located within the ligament which are necessary for proper functioning of joint proprioception. In addition, it is assumed that sensory disorders may significantly affect the occurrence of abnormalities in posture control [5].

Moreover, in patients with the ACL rupture there have been reported disorders of functioning of the muscles of the neck, head and trunk, leading to abnormal postural control. The stabilographic examination of these patients showed a significant anterior shift of the centre of pressure of the foot (CoP) in the sagittal plane and the shift towards the side in the frontal plane. It should therefore be stated that the ACL injury leads to impairment of its own function and, as a consequence, the biomechanics within the entire body is disturbed [6].

Negahban et al. after analyzing 12 studies clearly indicates that in patients with isolated ACL injury postural control is impaired in both legs, especially injured leg. The result of within-group difference in eyes open condition confirms bilateral deficit of postural control [7].

Kinesiotaping (KT) is a therapeutic method, supporting the process of rehabilitation in many diseases and injuries of the musculoskeletal system. It consists in sticking selected fragments of the body with special structure tapes. It directly affects the skin (mainly Ruffini's ends, receptors of pain, deep sensation), musculoskeletal and lymphatic system $[8,9]$.

Kinesiotaping method originates from Japan, where in the early 70's a Japanese chiropractic, the president of the Kinesiotaping Society, Dr. Kenzo Kase, began working on a new therapeutic method. He was the first to apply kinesiotaping in the treatment of joint disorders and rheumatism. In Europe, kinesiotaping has been used since 1996. Initially, kinesiotaping was mainly used in sport as a prevention of injuries and as a therapy supporting the treatment of injuries. Currently, it applies to practically every muscle and joint dysfunction. The purpose of the method is to use natural self-healing processes. KT uses special kinesio tapes, which are characterized by flexibility and extensibility only to the length, thanks to which it is possible to apply it to any part of the body with different tension, used depending on the type of application and the therapeutic result we want to achieve. The therapeutic effect of the tape is associated only with the appropriate technique of application. KT reduces muscle and joint pain, supports muscles and joints, corrects joint settings and removes lymphatic edema. The advantage of the method is primarily the fact that this technique does not limit joint movements and is not an obstacle to running the current lifestyle [10-12].

$\mathrm{KT}$ is the recommended and used method to improve coordination during standing and walking. KT is widely used in orthopedic, traumatic and neurological patients because it successfully improves static stability. Two theories can be found in the literature that describe the influence of KT on stability. The first theory assumes that KT significantly affects the structural stiffness of the joints, and thus constitutes a postural control mechanism. The second theory, on the other hand, describes the effect of KT on skin extensibility, which causes irritation of proprioreceptors and the transmission of sensory information to the central nervous system. The information from the sensory receptors improves the control of standing and posturę [3].

The literature describes widely the use of KT in the treatment of patients with many dysfunctions, as well as is used in the prevention and support of sports injury treatment $[9,10]$.

But in the literature there is no clear answer favouring the efficiency of KT in several motor function disorders. In many cases application of $\mathrm{KT}$ has brought expected results, on the other hand, many applications have not showed positive effects [13-15].

The use of stabilizing and muscle applications in improving muscle balance and strength in ankle injuries in athletes is described. Controversy arouses both the stabilization of the joint in the context of the obtained results of high-speed and proprioceptive action [16].

There are also many studies confirming the effectiveness of various KT applications in reducing inflammation and pain by increasing the flow of lymph and blood or increasing the range of motion [17-19].

In addition, the application of kinesiotaping in a patients who have been diagnosed with significant weakness of the quadriceps has resulted in a significant improvement in efficiency of the lateral and medial head of the quadriceps. Increasing the activity of these muscles may have a positive influence on improving the efficiency of the knee [20]. 
Considering the changes in postural control in patients with ACL rupture and the properties of $\mathrm{KT}$, it is therefore possible to use $\mathrm{KT}$ in improving standing stability?

Taking into account the above abnormalities in the body biomechanics in patients with ACL rupture, the possibility of application of the KT method in therapy and up to date, to the best of our knowledge there is, however no research on this subject, own research will present possible use of kinesiotaping for correction of changes in the motor system of patients with instability of the knee.

The aim of the study was to assess the early impact of the selected KT technique on the stability of the knee joint during standing position in patients with ACL rupture based on stabilographic parameters.

This study is based on the hypothesis that KT improves static stability of the knee joint in patients with ACL rupture during standing position.

\section{Methods}

\section{Design}

This pre-posttest repeated measure randomized singleblind, placebo-controlled trial was reported according to the recommendations of the CONSORT statement [21].

The first author (physiotherapist) enrolled 70 patients with ACL rupture. Those who qualified for the research were patients at the Department of Orthopaedics and Rehabilitation of University Hospital in Krakow.

Before starting the intervention, patients were randomly allocated to the experimental or placebo group by an independent researcher using the sealed envelopes method. Patients from placebo group were blinded after assignment to intervention.

Eligibility criteria for the research:

1. ACL rupture confirmed by imaging examination: MRI, CT SCAN.

2. The presence of no other injuries or illnesses which may affect the outcome of the tests (tests performed by an orthopedist).

3. After becoming acquainted with the purposes and the course of the research - a voluntary consent to participate in the study (written consent).

4. The patients had not taken medications which may affect motor coordination.

Exclusion criteria:

1. Injuries or illnesses which may affect the results (i.e. MCL/LCL/PCL injury, meniscus injury, degenerative changes in the joints of the leg).

2. Acute instability - surgery scheduled within one month from the injury.
3. Lack of patient's consent to participate in the research.

The examination was performed before ACL reconstruction and none of the patients had yet undergone preparation for the reconstruction in the form of preoperative rehabilitation, so it had no effect on the effect of KT.

The study lasted from 2015 to 2018 and was carried out at the University of Physical Education in Krakow in Laboratory of the Diagnostics of the Motor System, Laboratory of the Motion Analysis.

\section{Intervention}

During this research ligament technique of kinesiotaping (which limiting the anterior translation of the tibia) was taken into consideration. Application of a KT tape only on the injured knee was to stabilize the knee joint. One strip of an "I-type" KT was used. During the application, the patient was lying supine. The knee was flexed to $45^{\circ}$ (measured by goniometer).

The base of the measured KT piece was applied without tension at the height of the patella tendon. Then the tape with a tension of $75 \%$ was applied symmetrically on the medial and lateral sides of the knee up to the femur. In the ligament technique, the stretching of the tape oscillates between 75 and $100 \%$, because the maximum or submaximal extension of the tape supports passive joint stabilizers, which are unable to properly perform their function due to injury, in addition only such a force is able to maintain the dorsal glide [22, 23]. In own research, it was decided that all patients should have the same stretch of the tape, which amounted to 75 $\%$, because a $100 \%$ tension could cause damage to the skin during movement, as well as KT could peel off.

During the application, the patient was asked to extend the knee while the therapist applied the tape in the cranial-dorsal direction. The last $5 \mathrm{~cm}$ of tape were applied without tension on both the lateral and medial sides. (Fig. 1.)

The placebo group had a KT placebo application (with no tension on KT). Intervention and stabilographic test in the placebo group was the same as in the experimental group.

Analyses of results of injured leg for both groups were conducted twice:

1. at baseline - before application of KT,

2. after the application of KT.

After the application of kinesiotaping each patient had 1 hour to adjust to the application. This allowed early assessment of impact of the KT. 


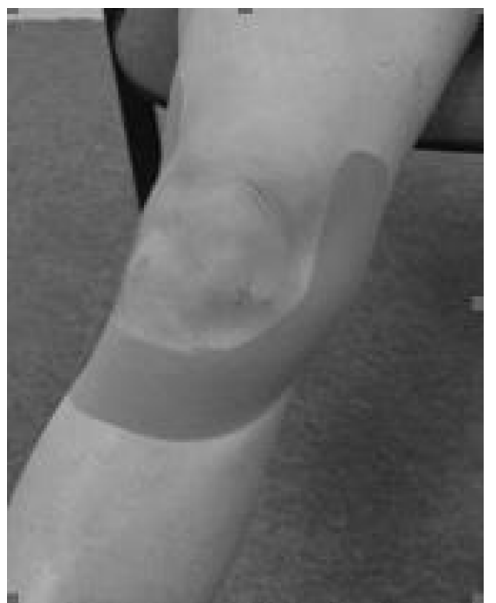

\section{Application of kinesio tape [own source]}

Fig. 1 Application of kinesio tape [own source]

There were 13 patients with the dominant injured limb and 19 with the undominant injured limb in the Experimental group and 18 patients with the dominant injured limb and 12 patients with the undominant injiured limb in Placebo group.

\section{Outcome measures}

The study used measurements of static stabilographic indicators with a stabilographic platform (primary outcomes) [24-26].

To assess stabilographic indicators a stabilographic platform CQStab2P ${ }^{\circ}$ (Czernica, Poland) was used. CQStab software was used to archive and process results $[27,28]$.

The analysis of the course of the statokinesiogram line shows that for the accuracy of its reproduction (accuracy $1 \mathrm{~mm}$ with a fluctuation radius of $10 \mathrm{~cm}$ ) the accuracy is $1 \%$. The 12 bit processing used (effective 10 bit) means the processing accuracy is $0.1 \%$.

Registration of the data was possible due to tensometric sensors placed on the surface of the platform. These sensors reacted to changes in pressure load of the patient's feet on the ground, by registering the displacement of the centre of pressure of the foot on the ground $(\mathrm{CoP})$. The results of the study were archived by charting changes in the position of CoP.

In the analysis of the results the following indices were used:

$S P$ - total path length, on both axes of rectangular coordinate YOX $[\mathrm{mm}]$,

$S P A P$ - statokinesiogram path length on the $\mathrm{Y}$ axis $[\mathrm{mm}]$, $S P M L$ - statokinesiogram path length on the $\mathrm{X}$ axis $[\mathrm{mm}]$. $\mathrm{MV}$ - mean velocity of the COP in XY (2D) axes $[\mathrm{mm} / \mathrm{s}]$. MVAP- mean velocity of the $\mathrm{CoP}$ in the $\mathrm{Y}$ axis $[\mathrm{mm} / \mathrm{s}]$.
MVML- mean velocity of the CoP in the $\mathrm{X}$ axis $[\mathrm{mm} / \mathrm{s}]$.

Each of the patients had the opportunity to test the position on the platform just before the actual measurements. This "pre-test" lasted about 15 minutes and was not included in the actual test.

The first test was done after the patient had rested in a sitting position for 5 minutes. The patient was standing freely, barefoot, with upper limbs placed along the body and straight legs. During the measurement, subjects had to focus attention on a graphic point placed at eye level, within $2 \mathrm{~m}$ from the platform. The patient was then asked to stand on injured leg and flex the other knee to such extent that touching the ground was impossible, without changing the settings of the hip. Patient could not connect lower limbs, support the elevated leg on the currently examined leg. The study was carried in silence, with natural daylight. Each measurement was made at the same time of the day.

During the first examination four 30 -second measurements were made (2 for each limb):

- Standing on the non-injured leg with eyes open (the opposite leg flexed in the knee).

- Standing on the injured leg with eyes open (the opposite leg flexed in the knee). (Fig. 2)

The results represent the averaged results from all measurements.

Then a physiotherapist applied KT. After the application of the tape and 1-hour break (with a 5-minute rest in a sitting position before the test) the second test was done. The test covered the same measurement as during test 1 . Duration of intervention was about 1 hour and 30 minutes.

The study also included the eye-closed test, but over $50 \%$ of patients did not complete the measurement, so only the results of the open-eye test were used in the analysis.

The results were compared with the control group.

The intervention was supervised by a physiotherapist (first author) who assessed whether the research was consistent with the methodology of the stabilographic examination and whether the KT application met the methodological assumptions.

\section{Statistical analysis}

The STATISTICA 12.0.PL software was used for statistical analysis. The first stage of the analysis was to check the normality of the distribution of variables using the Shapiro-Wilk test. The next step was to determine the significance of changes between the variables. Two-way ANOVA analysis (ANOVA group $\mathrm{x}$ time) was used. Multiple comparisons were based on the Bonferroni correction. Cohen's d allowed for the assessment of the effect size, which was analyzed in accordance with 

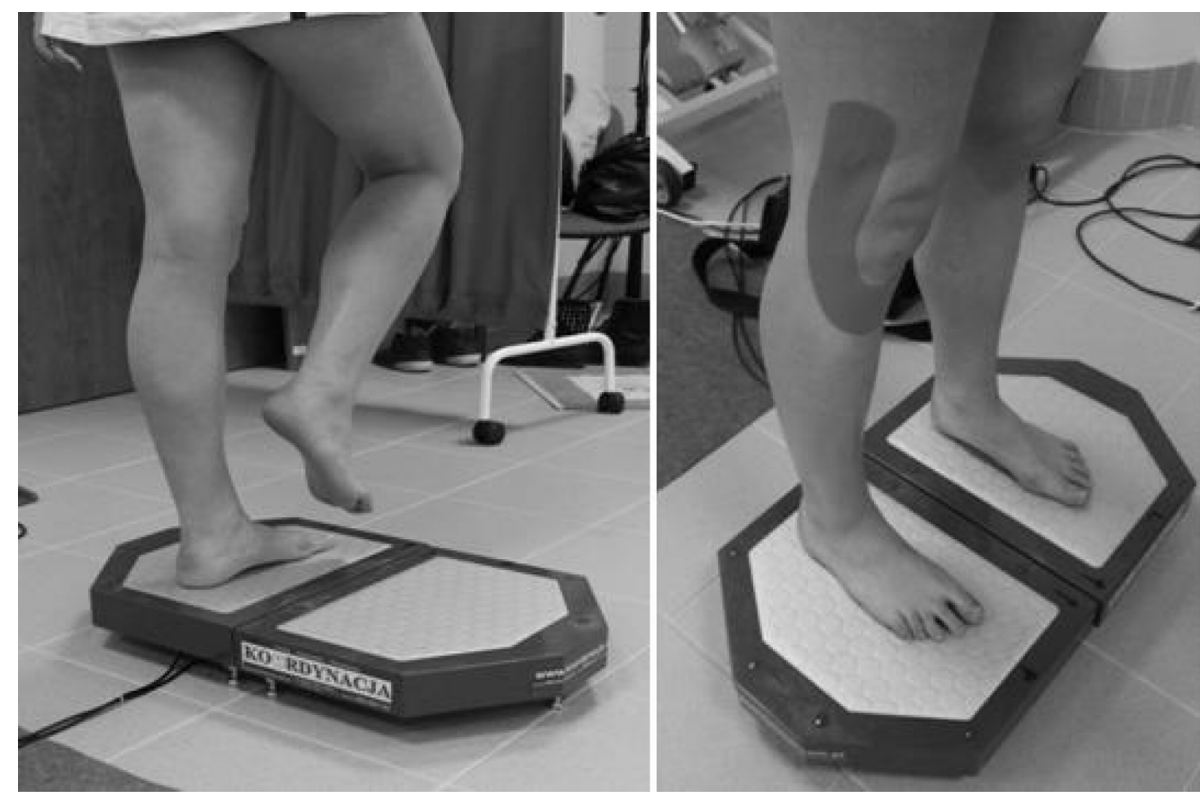

\section{Measurement of the stabilographic parameters. [own source]}

Fig. 2 Stabilographic test [own source]

previous studies [29-31]. The study assumed $p<0.05$. The paired t-test power analysis showed that at least 30 subjects were needed to obtain a power of 0.8 at a twosided level of 0.05 at an effect size of $d=0.6$.

\section{Results}

70 patients were enrolled to the research project. After randomization 33 patients were qualified to the experimental group and 32 to placebo group. The final experimental group consisted of 32 patients (20 men and 12 women) aged 20-57 years $(29.8 \pm 9.5)$ and placebo group comprised a group of 30 patients (23 men and 7 women) aged $20-55$ years $(28.16 \pm 6.17)$. (Table 1.) 5 patients were excluded in the research process (not meeting inclusion criteria $(\mathrm{n}=3)$, declined to participate $(\mathrm{n}=2)$. Figure 3. shows the qualification process for clinical trials.
All patients had been diagnosed (by an orthopaedist) with a complete ACL rupture within the knee joint (the average time between the injury and examination was 4 months +/- 2.4).

Analysis of the SP indicator results before and after the application of $\mathrm{KT}$ in the experimental group indicates a significant improvement $(p<0.001)$ over the placebo group $(p<0.060)$.

Statistical analysis in experimental group showed a significant shortening $(p<0.001)$ of SPAP path while standing one-legged on the injured limb before and after application of KT.

After the application of $\mathrm{KT}$, the results between the groups were statistically significantly different $(p=0.039)$. Improvement occurred in the experimental group.

Differences in measurements of the SPML variable before and after application of KT showed a statistically significant decrease in the SPML variable in

Table 1 Anthropometric data of the research group

\begin{tabular}{|c|c|c|c|c|c|}
\hline \multirow[t]{2}{*}{ Variable } & \multicolumn{2}{|c|}{ Experimental } & \multicolumn{2}{|l|}{ Placebo } & \multirow[t]{2}{*}{$p$} \\
\hline & $\mathrm{x} \pm \mathrm{SD}[\mathrm{yrs}]$ & Min-Max & $\mathrm{x} \pm \mathrm{SD}$ [yrs] & Min-Max & \\
\hline Age & $29.8 \pm 9.5$ & $20-57$ & $28.16 \pm 6.17$ & $20-55$ & 0.254 \\
\hline Height $[\mathrm{cm}]$ & $175.1 \pm 8.3$ & $158.5-193$ & $177.6 \pm 8.6$ & $160.5-189$ & 0.329 \\
\hline BMI & $25.3 \pm 3.2$ & $19.2-31.9$ & $24.6 \pm 4.4$ & $22.8-28.4$ & 0.254 \\
\hline time between the injury and examination [mths] & $4+/-2.4$ & & & & \\
\hline
\end{tabular}

Experimental experimental group; Placebo placebo group $\boldsymbol{p}<0,05$ 


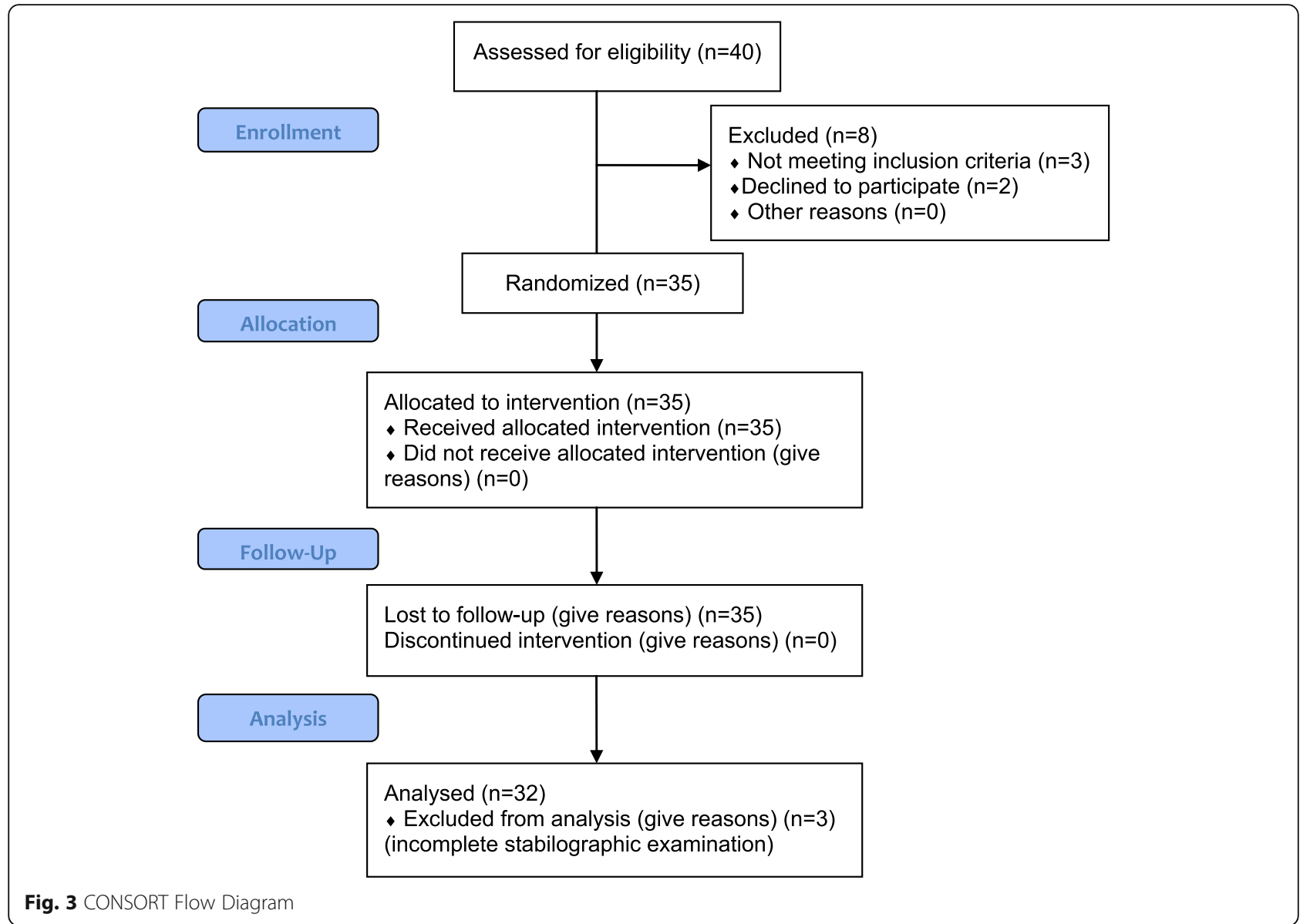

experimental group. After KT application, the difference in the SPML values between the groups was statistically significant $(\mathrm{p}=0.046)$ (Table 2.)

The analysis of the CoP velocity in the XY axes (MV) indicates a significant improvement in the results in the experimental group $(p=0.039)$. The comparison between the groups also indicates a significantly better result of the experimental group $(\mathrm{p}=0.042)$ after the application of KT. The results of the CoP velocity in the $\mathrm{Y}$ axis (MVAP) and X (MVML) also indicate significant improvements after KT application in the experimental group and between the groups.

The results of the variables between the injured side and the healthy side in both groups were also compared.

In the experimental group, before the KT application, the results of all indicators differed significantly between the sides. After the KT application, the values of the injured side approached the results of the healthy side, and the differences were not statistically significant. (Table 3.)

There were statistically significant differences between sides in both the Baseline and second measurement in all of the analysed variables in Placebo group. (Table 4.)

\section{Discussion}

Analysing the available literature, there is no information regarding the effectiveness of $\mathrm{KT}$ in the treatment of patients after a complete ACL ruptures. So far, no studies have been performed with the use of $\mathrm{KT}$ in improving the static stability of knee after one of the most frequent ligament injuries in the knee joint. Therefore, in this study the attempt was made to evaluate the effectiveness of selected ligamentous application of KT in cases of a complete ACL rupture. The aim of the study was to assess of the early impact of the selected KT technique on the static stability of the knee.

The presented research focuses on the evaluation of knee stability during standing position, evaluated by stabilographic platform.

Application of KT affected changes in the SPAP and SPML variables only in experimental group. The results show a statistically significant shortening of the statokinesiogram path length on the $\mathrm{Y}$ and $\mathrm{X}$ axes after application of $\mathrm{KT}$ in experimental group. It means that in terms of SPAP and SPML indicators, the KT application significantly improves static stability of the knee. The fact that the SPAP and SPML variables decreased after the KT application may indicate that the KT application 
Table 2 Comparsion of outcome variables characterizing the measurement of the SP, SPAP variable at baseline and after application of KT

\begin{tabular}{|c|c|c|c|c|c|c|}
\hline & & \multirow{2}{*}{$\begin{array}{l}\text { Baseline } \\
X \pm S D\end{array}$} & \multirow{2}{*}{$\begin{array}{l}\text { Post } \\
X \pm S D\end{array}$} & \multirow{2}{*}{$\begin{array}{l}X \text { difference } \\
(95 \% \mathrm{Cl})\end{array}$} & \multirow[t]{2}{*}{$p^{a}$} & \multirow[t]{2}{*}{$\mathrm{ES}^{\mathrm{a}}$} \\
\hline & & & & & & \\
\hline \multirow[t]{4}{*}{$\mathrm{SP}[\mathrm{mm}]$} & Experimental & $1107.3 \pm 288.8$ & $927.8 \pm 295.9$ & -179.5 (1.81 to 2.01$)$ & $<0.001$ & 0.61 \\
\hline & Placebo & $1073.9 \pm 266.5$ & $1033.1 \pm 289.2$ & -40.8 (1.45 to 2.56$)$ & 0.060 & 0.14 \\
\hline & $p^{b}$ & 0.638 & 0.043 & & & \\
\hline & $E S^{\mathbf{b}}$ & 0.11 & 0.36 & & & \\
\hline \multirow[t]{4}{*}{ SPAP $[\mathrm{mm}]$} & Experimental & $818.3 \pm 238.4$ & $622.4 \pm 254.8$ & -195.9 (2.05 to 2.91) & $<0.001$ & 0.79 \\
\hline & Placebo & $702.4 \pm 219.3$ & $698.1 \pm 217.5$ & -4.3 (1.01 to 3.01$)$ & 0.067 & 0.02 \\
\hline & $p^{b}$ & 0.464 & 0.039 & & & \\
\hline & $E S^{\mathbf{b}}$ & 0.50 & 0.32 & & & \\
\hline \multirow[t]{4}{*}{ SPML [mm] } & Experimental & $763.9 \pm 238.6$ & $681.2 \pm 234.0$ & $-82.7(2.21$ to 3.34$)$ & 0.031 & 0.35 \\
\hline & Placebo & $752.1 \pm 208.6$ & $728.6 \pm 194.8$ & $-63.5(1.26$ to 2.69$)$ & 0.221 & 0.11 \\
\hline & $p^{b}$ & 0.882 & 0.046 & & & \\
\hline & $\mathrm{ES}^{\mathbf{b}}$ & 0.05 & 0.22 & & & \\
\hline \multirow{4}{*}{$\begin{array}{c}\mathrm{MV} \\
{[\mathrm{mm} / \mathrm{s}]}\end{array}$} & Experimental & $36.7 \pm 8.7$ & $32.2 \pm 9.3$ & -4.5 (1.98 to 2.78$)$ & 0.039 & 0.49 \\
\hline & Placebo & $37.3 \pm \pm 9.9$ & $35.6 \pm 9.5$ & $-1.7(1.45$ to 2.21$)$ & 0.089 & 0.17 \\
\hline & $p^{b}$ & 0.079 & 0.042 & & & \\
\hline & $E S^{b}$ & 0.06 & 0.36 & & & \\
\hline \multirow{4}{*}{$\begin{array}{l}\text { MVAP } \\
{[\mathrm{mm} / \mathrm{s}]}\end{array}$} & Experimental & $23.2 \pm 5.8$ & $19.2 \pm 7.6$ & -4 (1.67 to 2.56$)$ & 0.043 & 0.59 \\
\hline & Placebo & $23.8 \pm 7.4$ & $22.2 \pm 7.9$ & $-1.6(1.75$ to 3.01$)$ & 0.079 & 0.20 \\
\hline & $p^{b}$ & 0.096 & 0.039 & & & \\
\hline & $E S^{b}$ & 0.09 & 0.38 & & & \\
\hline \multirow{4}{*}{$\begin{array}{l}\text { MVML } \\
{[\mathrm{mm} / \mathrm{s}]}\end{array}$} & Experimental & $24.4 \pm 6.8$ & $20.3 \pm 6.5$ & -4.1 (1.21 to 2.45$)$ & 0.031 & 0.61 \\
\hline & Placebo & $25.1 \pm 6.4$ & $23.1 \pm 6.2$ & -2 (0.92 to 3.42$)$ & 0.112 & 0.31 \\
\hline & $p^{b}$ & 0.065 & 0.024 & & & \\
\hline & $E S^{b}$ & 0.10 & 0.44 & & & \\
\hline
\end{tabular}

Baseline the measurement before application of KT; Post the measurement after application of KT; SPthe total path length; SPAP the path length on the Y axis; $S P M L$ the path length on the X axis; $M V$ mean velocity of the COP in XY axes; MVAP mean velocity of the CoP in the $Y$ axis; MVML mean velocity of the CoP in the $\mathrm{X}$ axis; $p^{a} p$-value; between baseline and post-KT within each group; $p^{b} p$-value between study groups; $E S^{a}$ effect size (Cohen d) within each group; $E S^{b}$ effect size (Cohen $\mathrm{d}$ ) between study groups; $p<0,05 ; \mathrm{Cl}$ confidence interval

causes a stimulation of mechanoreceptors, which enhances proprioception, joint position sense, and perception to avoid excessive movement.

The results of the SP variable were also analyzed. The results show a significant improvement in static stability in the experimental group after KT application. In the placebo group the result was not significant. It should therefore be concluded that the application $\mathrm{KT}$ reduces the value of sway at the CoP in terms of SP indicator.

The analysis of the results between the injured side and the healthy side in experimental group shows statistically significant differences. After KT application, the results improved significantly and came closer to the results of the healthy side. In the placebo group, both before and after the KT application, the indicators values differed significantly, which means that KT did not shorten the SP, SPAP and SPML pathways.
Based on the average COP velocity the nature of the balance dynamics can be defined. Low values of average velocity indicate a low dynamics of body balance control, so it can be assumed that the examined person is standing still. High values are evidence of the restless and sudden body movements [32].

Measurement of the CoP velocity in individual axes indicates a significant improvement of these parameters in the experimental group after the $\mathrm{KT}$ application. The reduction of velocity of the CoP deflection after $\mathrm{KT}$ application means that kinesiotaping decreased the CoP deflections, and thus the standing position was more stable.

The results suggest that the application of $\mathrm{KT}$ in participants with ACL rupture restores the SP, SPAP, SPML, MV, MVAP, MVAP indicators compared with the healthy side.

This may be due to the fact that thanks to the strong $\mathrm{KT}$ tension (75\%), the tape is able to provide stability to 
Table 3 Comparsion of outcome variables characterizing the measurement of the SP, SPAP variable at baseline and after application of KT between injured and healthy side in Experimental group

\begin{tabular}{|c|c|c|c|c|c|c|}
\hline & & \multirow{2}{*}{$\begin{array}{l}\text { Baseline } \\
X \pm S D\end{array}$} & \multirow{2}{*}{$\begin{array}{l}\text { Post } \\
X \pm S D\end{array}$} & \multirow{2}{*}{$\begin{array}{l}X \text { difference } \\
(95 \% \mathrm{Cl})\end{array}$} & \multirow[t]{2}{*}{$p^{a}$} & \multirow[t]{2}{*}{$\mathrm{ES}^{\mathrm{a}}$} \\
\hline & & & & & & \\
\hline \multirow[t]{4}{*}{$\begin{array}{c}\mathrm{SP} \\
{[\mathrm{mm}]}\end{array}$} & $\begin{array}{l}\text { Experimental } \\
\text { injured }\end{array}$ & $1107.3 \pm 288.8$ & $927.8 \pm 295.9$ & -179.5 (1.81 to 2.01$)$ & $<0.001$ & 0.61 \\
\hline & $\begin{array}{l}\text { Experimental } \\
\text { healthy }\end{array}$ & $945.3 \pm 319.47$ & $935.8 \pm 347.9$ & $-9.5(1.34$ to 1.56$)$ & 0.308 & 0.02 \\
\hline & $p^{b}$ & 0.043 & 0.132 & & & \\
\hline & $\mathrm{ES}^{\mathrm{b}}$ & 0.53 & 0.02 & & & \\
\hline \multirow[t]{4}{*}{$\begin{array}{l}\text { SPAP } \\
{[\mathrm{mm}]}\end{array}$} & $\begin{array}{l}\text { Experimental } \\
\text { injured }\end{array}$ & $818.3 \pm 238.4$ & $622.4 \pm 254.8$ & -195.9 (2.05 to 2.91$)$ & $<0.001$ & 0.79 \\
\hline & $\begin{array}{l}\text { Experimental } \\
\text { healthy }\end{array}$ & $644.8 \pm 394.9$ & $628.9 \pm 337.1$ & -15.9 (1.76 to 1.97$)$ & 0.478 & 0.04 \\
\hline & $p^{b}$ & 0.032 & 0.254 & & & \\
\hline & $\mathrm{ES}^{\mathbf{b}}$ & 0.53 & 0.02 & & & \\
\hline \multirow[t]{4}{*}{$\begin{array}{l}\text { SPML } \\
{[\mathrm{mm}]}\end{array}$} & $\begin{array}{l}\text { Experimental } \\
\text { injured }\end{array}$ & $763.9 \pm 238.6$ & $681.2 \pm 234.0$ & -82.7 (2.21 to 3.34$)$ & 0.031 & 0.35 \\
\hline & $\begin{array}{l}\text { Experimental } \\
\text { healthy }\end{array}$ & $690.4 \pm 276.3$ & $683.8 \pm 230.2$ & $-6,6(1.53$ to 1.79$)$ & 0.222 & 0.02 \\
\hline & $p^{b}$ & 0.045 & 0.632 & & & \\
\hline & $\mathrm{ES}^{\mathbf{b}}$ & 0.28 & 0.01 & & & \\
\hline \multirow[t]{4}{*}{$\begin{array}{c}\mathrm{MV} \\
{[\mathrm{mm} / \mathrm{s}]}\end{array}$} & $\begin{array}{l}\text { Experimental } \\
\text { injured }\end{array}$ & $36.7 \pm 8.7$ & $32.2 \pm 9.3$ & $-4.5(1.11$ to 1.43$)$ & 0.039 & 0.49 \\
\hline & $\begin{array}{l}\text { Experimental } \\
\text { healthy }\end{array}$ & $32.8 \pm 6.2$ & $31.7 \pm 5.9$ & 1.1 (1.54 to 2.01 ) & 0.121 & 0.18 \\
\hline & $p^{b}$ & 0.041 & 0.179 & & & \\
\hline & $\mathrm{ES}^{\mathbf{b}}$ & 0.51 & 0.06 & & & \\
\hline \multirow[t]{4}{*}{$\begin{array}{l}\text { MVAP } \\
{[\mathrm{mm} / \mathrm{s}]}\end{array}$} & $\begin{array}{l}\text { Experimental } \\
\text { injured }\end{array}$ & $23.2 \pm 5.8$ & $19.2 \pm 7.6$ & -4 (1.23 to 3.12$)$ & 0.043 & 0.59 \\
\hline & $\begin{array}{l}\text { Experimental } \\
\text { healthy }\end{array}$ & $18.8 \pm 4.1$ & $19.5 \pm 4.8$ & 0.7 (0.23 to 1.95$)$ & 0.097 & 0.15 \\
\hline & $p^{b}$ & 0.036 & 0.213 & & & \\
\hline & $\mathrm{ES}^{\mathbf{b}}$ & 0.87 & 0.04 & & & \\
\hline \multirow[t]{4}{*}{$\begin{array}{l}\text { MVML } \\
{[\mathrm{mm} / \mathrm{s}]}\end{array}$} & $\begin{array}{l}\text { Experimental } \\
\text { injured }\end{array}$ & $24.4 \pm 6.8$ & $20.3 \pm 6.5$ & $-4.1(0.34$ to 2.47$)$ & 0.031 & 0.61 \\
\hline & $\begin{array}{l}\text { Experimental } \\
\text { healthy }\end{array}$ & $19.6 \pm 5.9$ & $19.1 \pm 4.8$ & $-0.5(0.12$ to 2.11$)$ & 0.173 & 0.09 \\
\hline & $p^{b}$ & 0.046 & 0.095 & & & \\
\hline & $\mathrm{ES}^{\mathbf{b}}$ & 0.75 & 0.21 & & & \\
\hline
\end{tabular}

Experimental injured - injured side; Experimental healthy - healthy side

the joint, thus resulting in better control of the standing position, which reduces the $\mathrm{CoP}$ swaying.

In the research published to date, authors indicate the effectiveness of $\mathrm{KT}$ in the recovery of knee muscle strength in the course of the patellofemoral conflict or they state the usefulness of this method in the prevention of muscular injuries $[12,20,33$, $34]$. According to Kalron et al. there are data concerning the effectiveness of this method in the acute phase of musculoskeletal injuries [18]. There are, however, no clear scientific reports on outcomes of $\mathrm{KT}$, as well as studies assessing effectiveness of the therapy in most of the damage to the locomotor system among both patients and athletes. Similar conclusions were drawn by Mostafavifar et al. and Williams et al. [35, 36].

Kinesiotaping is also very often used in the prevention or treatment of sports injuries. However, also in this field of medicine, the results of research on its effectiveness are ambiguous. 
Table 4 Comparsion of outcome variables characterizing the measurement of the SP, SPAP variable at baseline and after application of KT between injured and healthy side in Placebo group

\begin{tabular}{|c|c|c|c|c|c|c|}
\hline & & \multirow{2}{*}{$\begin{array}{l}\text { Baseline } \\
X \pm S D\end{array}$} & \multirow{2}{*}{$\begin{array}{l}\text { Post } \\
X \pm S D\end{array}$} & \multirow{2}{*}{$\begin{array}{l}\text { X difference } \\
(95 \% \mathrm{Cl})\end{array}$} & \multirow[t]{2}{*}{$p^{a}$} & \multirow[t]{2}{*}{$\mathrm{ES}^{\mathrm{a}}$} \\
\hline & & & & & & \\
\hline \multirow[t]{4}{*}{$\begin{array}{l}\mathrm{SP} \\
{[\mathrm{mm}]}\end{array}$} & $\begin{array}{l}\text { Placebo } \\
\text { injured }\end{array}$ & $1073.9 \pm 266.5$ & $1033.1 \pm 289.2$ & $-40.8(1.45$ to 2.56$)$ & 0.060 & 0.14 \\
\hline & $\begin{array}{l}\text { Placebo } \\
\text { healthy }\end{array}$ & $967.3 \pm 219.77$ & $934.8 \pm 285.1$ & $-32.5(1.24$ to 1.64$)$ & 0.104 & 0.12 \\
\hline & $p^{b}$ & 0.049 & 0.045 & & & \\
\hline & $\mathrm{ES}^{\mathbf{b}}$ & 0.43 & 0.34 & & & \\
\hline \multirow[t]{4}{*}{$\begin{array}{l}\text { SPAP } \\
{[\mathrm{mm}]}\end{array}$} & $\begin{array}{l}\text { Placebo } \\
\text { injured }\end{array}$ & $702.4 \pm 219.3$ & $698.1 \pm 217.5$ & -4.3 (1.01 to 3.01$)$ & 0.067 & 0.01 \\
\hline & $\begin{array}{l}\text { Placebo } \\
\text { healthy }\end{array}$ & $625.8 \pm 234.1$ & $616.9 \pm 237.6$ & $-8.9(1.32$ to 1.84$)$ & 0.269 & 0.03 \\
\hline & $p^{b}$ & 0.027 & 0.018 & & & \\
\hline & $\mathrm{ES}^{\mathrm{b}}$ & 0.33 & 0.35 & & & \\
\hline \multirow[t]{4}{*}{$\begin{array}{l}\text { SPML } \\
{[\mathrm{mm}]}\end{array}$} & $\begin{array}{l}\text { Placebo } \\
\text { injured }\end{array}$ & $752.1 \pm 208.6$ & $728.6 \pm 194.8$ & -63.5 (1.26 to 2.69$)$ & 0.221 & 0.11 \\
\hline & $\begin{array}{l}\text { Placebo } \\
\text { healthy }\end{array}$ & $690.4 \pm 276.3$ & $683.9 \pm 230.2$ & $-6,5(1.23$ to 1.54$)$ & 0.138 & 0.02 \\
\hline & $p^{b}$ & 0.038 & 0.011 & & & \\
\hline & $\mathrm{ES}^{\mathbf{b}}$ & 0.25 & 0.23 & & & \\
\hline \multirow[t]{4}{*}{$\begin{array}{l}\mathrm{MV} \\
{[\mathrm{mm} / \mathrm{s}]}\end{array}$} & $\begin{array}{l}\text { Placebo } \\
\text { injured }\end{array}$ & $37.3 \pm 9.9$ & $35.6 \pm 9.5$ & -1.7 (1.11 to 2.34$)$ & 0.089 & 0.17 \\
\hline & $\begin{array}{l}\text { Placebo } \\
\text { healthy }\end{array}$ & $32.4 \pm 5.6$ & $31.8 \pm 4.7$ & $-0.6(0.97$ to 2.45$)$ & 0.076 & 0.11 \\
\hline & $p^{b}$ & 0.043 & 0.047 & & & \\
\hline & $\mathrm{ES}^{\mathbf{b}}$ & 0.60 & 0.50 & & & \\
\hline \multirow[t]{4}{*}{$\begin{array}{l}\text { MVAP } \\
{[\mathrm{mm} / \mathrm{s}]}\end{array}$} & $\begin{array}{l}\text { Placebo } \\
\text { injured }\end{array}$ & $23.8 \pm 7.4$ & $22.2 \pm 7.9$ & -1.6 (1.22 to 2.62$)$ & 0.079 & 0.20 \\
\hline & $\begin{array}{l}\text { Placebo } \\
\text { healthy }\end{array}$ & $19.5 \pm 5.9$ & $18.9 \pm 3.8$ & $-0.6(0.21$ to 1.31$)$ & 0.139 & 0.12 \\
\hline & $p^{b}$ & 0.039 & 0.042 & & & \\
\hline & $\mathrm{ES}^{\mathbf{b}}$ & 0.64 & 0.53 & & & \\
\hline \multirow[t]{4}{*}{$\begin{array}{l}\text { MVML } \\
{[\mathrm{mm} / \mathrm{s}]}\end{array}$} & $\begin{array}{l}\text { Placebo } \\
\text { injured }\end{array}$ & $25.1 \pm 6.4$ & $23.1 \pm 6.2$ & -2 (1.29 to 2.97$)$ & 0.112 & 0.31 \\
\hline & $\begin{array}{l}\text { Placebo } \\
\text { healthy }\end{array}$ & $19.9 \pm 3.9$ & $19.5 \pm 4.6$ & $-0.4(0.34$ to 2.49$)$ & 0.177 & 0.10 \\
\hline & $p^{b}$ & 0.047 & 0.034 & & & \\
\hline & $\mathrm{ES}^{\mathrm{b}}$ & 0.98 & 0.69 & & & \\
\hline
\end{tabular}

Placebo injured - injured side; Placebo healthy - healthy side

Williams et al. analyzed 97 articles describing the effectiveness of $\mathrm{KT}$ in the treatment and prevention of sports injuries [36]. The results of their analysis indicate that the effectiveness of $\mathrm{KT}$ in the treatment of pain, improvement in muscle strength, range of motion and the impact on proprioception are ambiguous and controversial with small beneficial results. They recommend further experimental studies on the effectiveness of $\mathrm{KT}$ in sport..
Unfortunately, there are no studies on the effectiveness of $\mathrm{KT}$ in regaining or maintaining static stability of the knee. There are reports suggesting that the use of KT has a positive effect on proprioception in patients with an ACL rupture during gait. Therefore, the application may improve gait pattern as well as the improve subjective function of the affected knee joint [37]. Bischoff et al. made such conclusions only on the basis of gait analysis [37]. In turn, Liu et al. investigated whether KT 
application improves proprioception, balance, and functional performance in patients with ACL rupture [38]. The KT muscle application on the quadriceps was used. Proprioception, balance, and functional performance were assessed after KT application using the Lysholm scale, anteroposterior shift of the tibia, active angle reproduction test, modified star excursion balance test, and single-hop distance. They concluded that KT has benefits in people with ACL rupture but cannot fully compensate for functional deficits. KT could be used to assist knee strengthening during rehabilitation.

There are also studies available in the literature concerning the assessment of the stability of the knee joint after ACL reconstruction. According Aghdam et al. the standing stability after ACL reconstruction decreased significantly, which may be due to the effects of the surgery on sensory mechanism of ACL and inability of patients to return to their previous deep sense perception and knee proprioception [39]. On the other hand, Ogrodzka-Ciechanowicz et al. claim that after the ACL reconstruction and individual rehabilitation the static stability of the knee improves [40].

Therefore, the results of own research make an important contribution to the analysis of the effectiveness of the $\mathrm{KT}$ ligamentous technique after ACL rupture. It can be concluded that application of KT reduces the value of sway at the CoP in patients with ACL rupture. This in turn results in better static stability of the joint and body posture. The obtained results indicate the effectiveness of KT in improving the static stability of the knee after ACL rupture. The application, which was evaluated, directly affects the standing stability of the knee. It maintains a proper dorsal glide, thus blocking the giving-way syndrome, which is the cause of significant movement limitations of patients after the ACL rupture.

The beneficial effect of the KT is explained by its impact on the axial positioning of joints, which improves their stability.

While selecting the appropriate therapy for the patient after ACL rupture one should keep in mind that KT can be part of it, but should not be used as a single method in order to achieve best results.

The stability of the knee joint results from several factors influencing one other, such as anatomy of a joint, body weight and loads acting on the joint. On the one hand, bone structure does not provide joint stability. However, ligaments, articular capsule and other soft tissues surrounding the joint are important in maintaining proper joint control. During physical activity pressure forces acting on a joint (resulting from body weight and activity of muscles) protect it additionally [41].

In the case of ACL injury, the stabilizing function can be taken over by other articular structures, but this requires appropriate training. By adding the KT method into therapy, which according to its assumptions is to perform a stabilizing function, you can expect an improvement in static control of body posture.

The conducted own research indicates the need for the continuation of the undertaken issue. A growing number of patients after ACL rupture and their increasing expectations regarding the effectiveness of treatment incline to broadly analyse of the problem. The diagnosis should include all indicators that may contribute to an increase in a patient's satisfaction, but also to minimise injury complications. In assessing the effectiveness of therapy, it is therefore purposeful to use stabilometric platforms which should become the standard in the diagnosis of patients after ACL rupture.

The limitation of the conducted research was the small number of comparable studies. This was the first study using the CQStab2P stabilographic platform to assess the effectiveness of $\mathrm{KT}$ among people with ACL rupture. This impeded the discussions on the data, but at the same time reflected the unique design of the study. Further research is needed on the effectiveness of KT in the treatment of patients with ACL rupture based on postural control assessment to determine clinical outcomes and allow discussion of its clinical relevance.

Summarising the above results, it should be concluded that after applying KT there is reduced sway of the CoP, which means the patient has more control over standing. The results obtained are conducive to the effectiveness of application of the selected KT technique in patients after ACL rupture. It seems, however, that the issues related to $\mathrm{KT}$ and its performance or lack of influence on the improvement of human body movement requires further research, taking into account other aspects of the problem studied. The more that there are few reports in the literature evaluating the effectiveness of $\mathrm{KT}$ in the context of improving static stability.

\section{Conclusions}

1. Application of KT in patients after ACL rupture shortened the total path length and improved the value of parameters in the frontal and sagittal planes in experimental group, which may suggest the potentially greater improvement in these parameters.

2. KT application decreased CoP displacement velocity values in particular axes, which means increased improvement in the control of standing position.

3. By improving the values of the analyzed variables, the KT application is able to compensate for the loss of static stability of the knee. 


\section{Practical Implications}

1. Application of $\mathrm{KT}$ in the treatment of patients with a complete ACL rupture has beneficial early effect on achieving static stability, assuming that this is a method supporting the treatment of patients with ACL rupture.

2. KT method could be a therapy offered for patients preparing for surgery of ACL reconstruction.

3. KT method should be prescribed for patients with musculoskeletal injuries, as suggested by the creators of $\mathrm{KT}$.

\begin{abstract}
Abbreviations
ACL: Anterior Cruciate Ligament; CoP: Centre Of Pressure of the Foot; $K T$ : Kinesiotaping; SP: Total path length, on both axes of rectangular coordinate YOX [mm]; SPAP: Statokinesiogram path length on the Y axis [mm]; SPML: Statokinesiogram path length on the $X$ axis $[\mathrm{mm}]$
\end{abstract}

\section{Acknowledgements}

Publication financed under the program of the Minister of Science and Higher Education under the name 'Regional Initiative of Excellence' in 20192022 project number 022 / RID / 2018/19 in the amount of PLN 11,919,908.

\section{Authors' contributions \\ KOC - research idea, research plan development, data collection, data analysis, literature search, manuscript writing, manuscript approval; GG - research idea, development of research plan, literature search, manuscript writing, manuscript approval; JŚ - patients recruitment, data analysis, manuscript approval; AG - patients recruitment, research, manuscript approval; JN - patients recruitment, research, manuscript approval. All authors have read and approved the manuscript.}

\section{Funding}

This study has received no funding.

\section{Availability of data and materials}

The datasets used and/or analysed during the current study are available from the corresponding author on reasonable request.

\section{Declarations}

Ethics approval and consent to participate

The research project obtained approval of the Bioethics Commission at the Regional Medical Chamber in Krakow. No. 19/KBL/OIL/2014 and participants provided written informed consent for participation in this study.

\section{Consent for publication}

Not applicable.

\section{Competing interests}

The author(s) declare(s) that they have no competing interests.

\section{Author details}

'Institute of Clinical Rehabilitation, Faculty of Motor Rehabilitation, Institute of Physical Rehabilitation, University of Physical Education, Al. Jana Pawla II 78, 31-571 Krakow, Poland. ${ }^{2}$ Department of Orthopedics and Traumatology, University Hospital, Krakow, Poland. ${ }^{3}$ Department of Orthopaedics and Physiotherapy, Jagiellonian University Collegium Medicum, Kraków, Poland. ${ }^{4}$ Liesing Orthopedic Center, Vienna, Austria.

Received: 17 November 2020 Accepted: 21 February 2021 Published online: 16 March 2021

\section{References}

1. Perry J, Burnfield J. Gait Analysis Normal and Pathological Function. New Jersey: Slack Incorporated; 2011.
2. Bartels T, Brehme K, Pyschik M, Schulze S, Delank KS, Fieseler G, et al. Preand postoperative postural regulation following anterior cruciate ligament reconstruction. J Exerc Rehabil. 2018;14(1):143-51 https://doi.org/10.12965/ jer.1835204.602

3. Pourmomeny AA, Jalaee F, Baharloo H, Karimi M. The Immediate Effects of Inhibitive Gastrocnemius Kinesio Taping on Static and Functional Balance Performance in Subjects With Chronic Stroke Disorders. PTJ. 2016;6(3):14954 https://doi.org/10.18869/nrip.ptj.6.3.149.

4. Brattinger F, Stegmüller B, Riesner H. Anterior cruciate ligament ruptures and postural correlation of functional knee scores with computerized dynamic posturography. Orthopade. 2013;42(2):100-6 https://doi.org/10.1 007/s00132-012-2040-6.

5. Piontek T, Ciemniewska-Gorzela K, Szulc A, Pyda A, Dudzinski W, Hejna R. Postural control strategy in patients with anterior cruciate ligament deficiency. Chir Narzadow Ruchu Ortop Pol. 2009;74(6):353-60.

6. Tecco S, Salini V, Calvisi V, Colucci C, Orso CA, Festa F, et al. Effects of anterior cruciate ligament (ACL) injury on postural control and muscle activity of head, neck and trunk muscles. J Oral Rehabil. 2006;33(8):576-87 https://doi.org/10.1111/j.1365-2842.2005.01592.x.

7. Negahban H, Mazaheri M, Kingma I. van Dieën J. A systematic review of postural control during single-leg stance in patients with untreated anterior cruciate ligament injury. Knee Surg Sports Traumatol Arthrosc. 2014;22:4911504 https://doi.org/10.1007/s00167-013-2501-4.

8. Wilson V, Douris P, Fukuroku T, Kuzniewski M, Dias J, Figueiredo P. The immediate and long-term effects of kinesiotape ${ }^{\oplus}$ on balance and functional performance. Int I Sports Phys Ther. 2016;11(2):247-53.

9. Kase K, Wallis J, Kase T. Clinical therapeutic applications of the Kinesio taping method. 3rd ed. Tokio: Kinesio Taping Association International; 2013.

10. Reynard F, Vuistiner P, Léger B, Konzelmann M. Immediate and short-term effects of kinesiotaping on muscular activity, mobility, strength and pain after rotator cuff surgery: a crossover clinical trial. BMC Musculoskelet Disord. 2018;19:305-16 https://doi.org/10.1186/s12891-018-2169-5.

11. De Hoyo M, Álvarez-Mesa A, Sańudo B, Carrasco L, Domínguez S. Immediate effect of kinesio taping on muscle response in young elite soccer players. J Sport Rehabil. 2013;22(1):53-8 https://doi.org/10.1123/jsr.22.1.53.

12. Vercelli S, Sartorio F, Foti C, Colletto L, Virton D, Ronconi G, et al. Immediate effects of kinesiotaping on quadriceps muscle strength: a single-blind, placebo-controlled crossover trial. Clin J Sport Med. 2012;22(4):319-26 https://doi.org/10.1097/JSM.0b013e31824c835d.

13. Castro-Sanchez A, Lara-Palomo I, Mataran-Penarrocha G, Fernández-Sánchez M, Sánchez-Labraca N, Arroyo-Morales M. Kinesio Taping reduces disability and pain slightly in chronic non-specific low back pain: a randomized trial. $J$ Physiother. 2012;58(2):89-95 https://doi.org/10.1016/S1836-9553(12)70088-7.

14. Kaya E, Zinnuroglu M, Tugcu I. Kinesio taping compared to physical therapy modalities for the treatment of shoulder impingement syndrome. Clin Rheumatol. 2011;30(2):201-7 https://doi.org/10.1007/s10067-010-1475-6.

15. Thelen M, Dauber J, Stoneman P. Clinical efficacy of kinesio tape for shoulder pain: A randomized double-blinded clinical trial. J Orthop Sports Phys Ther. 2008;38(7):389-95 https://doi.org/10.2519/jospt.2008.2791.

16. Nakajima MA, Baldridge $C$. The effect of kinesio tape on vertical jump and dynamic postural control. Int J Sports Phys Ther. 2013;8(4):393-406.

17. Chang HY, Wang CH, Chou KY, Cheng SC. Could forearm Kinesio Taping improve strength, force sense, and pain in baseball pitchers with medial epicondylitis? Clin J Sport Med. 2012;22(4):327-33 https://doi.org/10.1097/ JSM.0b013e318254d7cd.

18. Kalron A, Bar-Sela S. A systematic review of the effectiveness of Kinesio Taping ${ }^{\oplus}$ - Fact or fashion? Eur J Phys Rehabil Med. 2013;49(5):699-709.

19. Nunes GS, De Noronha M, Cunha HS, Ruschel C, Borges NG Jr. Effect of kinesio taping on jumping and balance in athletes: a crossover randomized controlled trial. J Strength Cond Res. 2013;27(11):3183-9 https://doi.org/10.1 519/JSC.0b013e31828a2c17.

20. Chen PL, Wei Hsien H, Lin CH, Chen WC. Biomechanics Effects of Kinesio Taping for Persons with Patellofemoral Pain Syndrome During Stair Climbing. In: Chen 4th Kuala Lumpur International Conference on Biomedical Engineering 2008 IFMBE Proceedings, vol. 8; 2008. p. 395-7.

21. Schulz KF, Altman DG, Moher DCONSORT, Group. CONSORT 2010 Statement: updated guidelines for reporting parallel group randomized trials. Ann Intern Med. 2010;152:726-732. https://doi.org/10.1136/bmj.c332.

22. Kase K, Wallis J, Kase T. Clinical Therapeutic Applications of the Kinesio Taping Method. 2nd ed. Tokyo: Albuquerque: Kinesio Taping Assoc; 2003. 
23. Limroongreungrat W, Boonkerd C. Immediate effect of ACL kinesio taping technique on knee joint biomechanics during a drop vertical jump: a randomized crossover controlled trial. BMC Sports Sci Med Rehabil. 2019; 11(32):1-7 https://doi.org/10.1186/s13102-019-0144-6.

24. Ageberg E, Roberts D, Holmström E, Friden T. Balance in single-limb stance in healthy subjects - reliability of testing procedure and the effect of shortduration sub-maximal cycling. BMC Musculoskelet Disord. 2003;4:14-9 https://doi.org/10.1186/1471-2474-4-14.

25. Birmingham TB. Test-retest reliability of lower extremity functional in stability measures. Clin J Sport Med. 2000;10:264-8 https://doi.org/10.1097/ 00042752-200010000-00007.

26. Ocetkiewicz T, Skalska A, Grodzicki T. Balance estimation by using the computer balance platform: repeatability of the measurements. Ger Pol. 2006;14(3):144-8.

27. Cultrera P, Pratelli E, Petrai V, Postiglione M, Zambelan G, Pasquetti P. Evaluation with stabilometric platform of balance disorders in osteoporosis patients. A proposal for a diagnostic protocol. Clin Cases Miner Bone Metab. 2010;7(2):123-5.

28. Mika A, Oleksy $Ł$, Kielnar R, Świerczek M. The influence of high- and low-heeled shoes on balance in young women. Acta Bioeng Biomech. 2016;18(3):97-103.

29. Tryon WW. Evaluating statistical difference, equivalence, and indeterminacy using inferential confidence intervals: an integrated alternative method of conducting null hypothesis statistical tests. Psychol Methods. 2001;6:371-86 https://doi.org/10.1037/1082-989X.6.4.371.

30. Nakagawa S, Cuthill IC. Effect size, confidence interval and statistical significance: a practical guide for biologists. Biol Rev Camb Philos Soc. 2007: 82:591-605 https://doi.org/10.1111/j.1469-185X.2007.00027.X.

31. Dunst CJ, Hamby DW. Guide for calculating and interpreting effect sizes and confidence intervals in intellectual and developmental disability research studies. J Intellect Develop Disabil. 2012;37:89-99 https://doi.org/1 0.3109/13668250.2012.673575.

32. Wyszyńska J, Drzał-Grabiec J, Podgorska-Bednarz J, Pop T, Snela S. Assessment of Balance women over 60 years of age. Adv Rehabil. 2015;1: 31-7 https://doi.org/10.1515/rehab-2015-0017.

33. Kuru T, Yalıman A, Dereli E. Comparison of efficiency of Kinesio taping and electrical stimulation in patients with patellofemoral pain syndrome. Acta Orthop Traumatol Turc. 2012;46(5):385-92 https://doi.org/10.3944/aott.2012.2682.

34. Wong OM, Cheung RT, Li R. Isokinetic knee function in healthy subjects with and without Kinesio taping. Phys Ther Sport. 2012;13(4):255-8 https:// doi.org/10.1016/j.ptsp.2012.01.004.

35. Mostafavifar M, Wertz J, Borchers J. A systematic review of the effectiveness of kinesio taping for musculoskeletal injury. Phys Sportsmed. 2012;40(4):3340 https://doi.org/10.3810/psm.2012.11.1986.

36. Williams $S$, Whatman C, Hume P, Sheerin K. Kinesio taping in treatment and prevention of sports injuries: a meta-analysis of the evidence for its effectiveness. Sports Med. 2012;42(2):153-64 https://doi.org/10.2165/11594 960-000000000-00000.

37. Bischoff L, Babisch C, Babisch J, Layher F, Sander K, Matziolis G, et al. Effects on proprioception by Kinesio taping of the knee after anterior cruciate ligament rupture. Eur J Orthop Surg Traumatol. 2018;28:1157-64 https://doi. org/10.1007/s00590-018-2167-1.

38. Liu K, Qian J, Gao Q, Ruan B. Effects of Kinesio taping of the knee on proprioception, balance, and functional performance in patients with anterior cruciate ligament rupture: A retrospective case series. Medicine. 2019;98(48):e17956 https://doi.org/10.1097/MD.0000000000017956.

39. Aghdam HA, Kavyani M, Bosak M, Karimi MT, Motififard M. Evaluation of the Stability of the Subjects with Anterior Cruciate Injuries Reconstruction. J Knee Surg. 2020. https://doi.org/10.1055/s-0040-1710374 Epub ahead of print. PMID: 32512593.

40. Ogrodzka-Ciechanowicz K, Czechowska D, Chwała W, Ślusarski J, Gądek A. Stabilometric indicators as an element of verifying rehabilitation of patients before and after reconstruction of anterior cruciate ligament. Acta Bioeng Biomech. 2018;20(1):101-7 PMID: 29658518.

41. Williams GN, Chmielewski T, Rudolph K, Buchanan TS, Snyder Mackler L. Dynamic knee stability: current theory and implications for clinicians and scientists. J Orthop Sports Phys Ther. 2001;31:546-66 https://doi.org/10.251 9/jospt.2001.31.10.546.

\section{Publisher's Note}

Springer Nature remains neutral with regard to jurisdictional claims in published maps and institutional affiliations.

\section{Ready to submit your research? Choose BMC and benefit from:}

- fast, convenient online submission

- thorough peer review by experienced researchers in your field

- rapid publication on acceptance

- support for research data, including large and complex data types

- gold Open Access which fosters wider collaboration and increased citations

- maximum visibility for your research: over $100 \mathrm{M}$ website views per year

At BMC, research is always in progress.

Learn more biomedcentral.com/submissions 